\title{
USE OF SOFTWARES FOR POSTURE ASSESSMENT: INTEGRATIVE REVIEW
}

\author{
O USO DE SOFTWARES PARA AVALIAÇÃO POSTURAL: REVISÃO INTEGRATIVA \\ USO DE SOFTWARES PARA LA EVALUACIÓN POSTURAL: REVISIÓN INTEGRADORA
}

Edyla Maria Porto de Freitas Camelo', Douglas Matias Uchôa², Francisco Fleury Uchoa Santos-Junior², Thiago Brasileiro de Vasconcelos', Raimunda Hermelinda Maia Macena ${ }^{1}$

\begin{abstract}
To carry out an integrative literature review on the postural analysis softwares available today. It is an integrative-narrative review of qualitative and methodological nature performed during April-July 2014. As inclusion criteria, the articles should be bibliographical or original research and available with full access. At first, we proceeded to the identification of the keywords for the softwares related to postural assessment commonly used in the health field, in such case "posture", "software", and "postural assessment". The search was narrowed by publication date from 2002 to 2014. Through the information acquired from the articles and from the software developers, information on 12 programs that assist the postural evaluation were obtained - Alcimage, All Body Scan 3D, Aplob, APPID, Biotonix, Corporis Pro, Fisimetrix, Fisiometer Posturograma, Physical Fisio, Physio Easy, Posture Print and SAPO. However, only one tool has more information and studies, namely SAPO. There are many postural analysis softwares available on the internet today, however, these are quite disparate in relation to possible answers and are still poorly widespread as research tools.
\end{abstract}

Keywords: Posture; Software; Outcome assessment (Health care).

\section{RESUMO}

Realizar uma revisão integrativa da literatura sobre os softwares de análise postural disponíveis na atualidade. Trata-se de uma revisão integrativa-narrativa, de cunho metodológico e natureza qualitativa, realizada no período de abril a julho de 2014 . Como critérios de inclusão, os artigos deveriam ser de natureza bibliográfica ou de pesquisa original e disponibilizados com acesso completo. A princípio, realizou-se a identificação de descritores relativos aos softwares relacionados à avaliação postural comumente utilizados no âmbito da saúde; sendo assim, os descritores foram "postura", "software" e "avaliação postural". As buscas foram estreitadas por data de publicação de 2002 a 2014. Diante das informações adquiridas a partir dos artigos e informações fornecidas pelos desenvolvedores dos softwares, foram obtidas informações sobre 12 programas que auxiliam a avaliação postural - Alcimage, All Body Scan 3D, Aplob, APPID, Biotonix, Corporis Pro, Fisimetrix, Fisiometer Posturograma, Physical Fisio, Physio Easy, Posture Print e SAPO. Entretanto, apenas uma ferramenta possui maior quantidade de informação e estudos realizados, o SAPO. Muitos são os softwares de análise postural disponíveis na internet atualmente, porém, são bastante díspares com relação às possibilidades de resposta e ainda são pouco difundidos como ferramentas de pesquisa.

Descritores: Postura; Software; Avaliação de resultados (Cuidados de saúde).

\section{RESUMEN}

Realizar una revisión integradora de la literatura sobre los softwares de análisis postural disponibles en la actualidad. Se trata de una revisión integradora-narrativa de carácter cualitativo y metodológico llevada a cabo durante abril y julio 2014. Como criterios de inclusión, los artículos debieran ser de naturaleza bibliográfica o de investigación original y disponibles con acceso completo. En un primer momento, se realizó la identificación de los descriptores para los softwares relacionados con la evaluación postural comúnmente utilizados en el campo de la salud, por lo tanto, los descriptores fueron "postura", "software" y "evaluación postural." La búsqueda se redujo por fecha de publicación, de 2002 a 2014. Teniendo en cuenta la información obtenida de los artículos y proporcionada por los desarrolladores de software, se obtuvieron informaciones sobre 12 programas que auxilian la evaluación postural - Alcimage, All Body Scan 3D, Aplob, APPID, Biotonix, Corporis Pro, Fisimetrix, Fisiometer Posturograma, Physical Fisio, Physio Easy, Posture Print y SAPO. Sin embargo, sólo una herramienta cuenta con toda la información y los estudios, a saber, SAPO. Hay muchos softwares de análisis postural disponibles en Internet actualmente, aunque sean bastante disímiles en relación a las posibles respuestas y todavía no se hayan difundido como herramientas de investigación.

Descriptores: Postura; Software; Evaluación de resultado (Atención de salud).

1. Universidade Federal do Ceará, Fortaleza, $C E$, Brazil.

2. Faculdade Maurício de Nassau, Fortaleza, CE, Brazil.

Study conducted in the Physiotherapy Department of Universidade Federal do Ceará, Fortaleza, CE, Brazil.

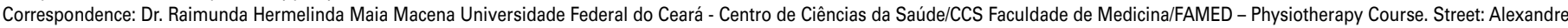
Baraúna, 949. District: Rodolfo Teófilo. Fortaleza, CE, Brazil. 60430-110. lindamacena@ gmail.com 


\section{INTRODUCTION}

Body posture increasingly reflects the lifestyle adopted by the population on a day-to-day basis. Postural problems originating in early childhood become important and can be caused by trauma, emotional, sociocultural and hereditary factors, and inappropriate clothing. ${ }^{1}$ Therefore, the earlier postural change is detected, the better the therapeutic responses and the less dismal the prognosis. ${ }^{2}$ Likewise, the earlier steps are taken to prevent postural problems, the more remote the chance of their appearance. Postural orientation is one of the best resources to be adopted and should emphasize spinal biomechanics and the effect that the environment exerts on the posture of individuals., 3

The assessment of posture in the standing position has been extensively employed for decades, both in clinical medicine and in scientific research activities, and is considered one of the basic instruments throughout the cycle of postural health, from diagnosis to prognosis, ${ }^{5,6}$ essential for the planning and monitoring of therapeutic conduct. ${ }^{7}$

Postural changes are more common than we realize, have considerable incidence in both non-athletes and athletes, and may even lead to functional incapacity. ${ }^{8}$ We have two main forms of posture assessment: the qualitative form - which is the most inexpensive and widely used, and is based on the practice and on the visual assessment of the therapist and the quantitative form - which uses photogrammetry as a resource, allowing a computer-aided assessment. ${ }^{9}$

Despite the growing number of surveys using digital photogrammetry (e.g. Alcimage, All Body Scan 3D, Aplob - Posture Assessment of the Biophysics Laboratory, APPID - Posture assessment based on digital imaging, Biotonix, Corporis Pro, Fisimetrix, Fisiometer Posturogram, Physical Fisio, Physio Easy, Posture Print, and Software for Posture Assessment - SAPO), the reliability of the method still needs to be enhanced. ${ }^{10}$ It is worth emphasizing that a consensus has not yet been reached on the most appropriate software, as there is no standardization of the angles used to verify certain postural changes, and studies on the reliability and reproducibility of posture assessment programs are still scarce. Accordingly, the aim of this study was to conduct an integrative review of literature on posture analysis software available nowadays, describing its applicability, similarities and differences.

\section{METHODOLOGY}

This is an integrative-narrative methodological review of a qualitative nature carried out between April and July 2014. The election of the integrative review method was due to the fact that it allows us to synthesize finished studies and to reach conclusions based on a topic of interest. A well designed integrative review requires the same standards of rigor, clarity and replication used in primary studies. ${ }^{11,12}$

The following stages were completed to prepare this review:

\section{Selection of thematic questions}

- Which software is most suitable for posture assessment?

- Which software is most complete for assisting in posture assessment?

\section{Establishment of criteria for the selection of studies to form the sample}

Inclusion criteria: the articles had to be in the form of a bibliography or original research, written in Portuguese, English or Spanish, providing complete online access. Exclusion criteria: content not related to the research question; title inconsistent with the study subject; articles indexed in more than one database and low methodological quality, such as important methodological information absence, presence of bias, and others.

\section{Analysis of data, interpretation of results and presentation of the review}

The first step was the identification of keywords relative to the software related to posture assessment commonly used within the sphere of health. Hence the keywords were "posture", "software" and "posture assessment". Searches were narrowed down by publication date, from 2002 to 2014

There was also a systematic review of national and international journals available in the Virtual Health Library, or Biblioteca Virtual de Saúde (BVS), indexed in the databases: LILACS (Latin American and Caribbean Health Sciences Literature), IBECS, MEDLINE, Cochrane, SciELO (Scientific Electronic Library Online); PubMed; PEDro (The Physiotherapy Evidence Database); CAPES Portal of Journals, ScienceDirect and Google Scholar. However, in view of the shortage of studies located directly in the virtual bases, the decision was made to add the search in the websites corresponding to the software cited in the studies. This research was conditioned by three investigators, in a blinded and separate manner, followed by subsequent cross-referencing of rhe findings.

The titles and abstracts of the articles were read first with the purpose of identifying the references that would fulfill the pre-established criteria.

After the thorough reading of the studies, it was possible to identify and structure the text through the following software: Alcimage, All Body Scan 3D, Aplob, APPID, Biotonix, Corporis Pro, Fisimetrix, Fisiometer Posturogram, Physical Fisio, Physio Easy, Posture Print and SAPO.

\section{RESULTS AND DISCUSSION}

The sample was composed of 11 articles selected according to the inclusion and exclusion criteria. Of these, only one is in English and the others are in Portuguese. The study initially contained 15 articles; however, one article did not have its full text made available, and three articles had titles that were inconsistent with the subject matters and objectives of the studies performed. (Figure 1)

Table 1 presents the categorization of the articles in terms of the year, title, authors, database of location and type of study. ${ }^{13-22}$

Due to the information acquired from the articles and information provided from the software developers through the corresponding sites, information was obtained about 12 types of software that assist in posture assessment, and are presented in Table 2 and described below.

With the advance of technology and the expansion of access to IT resources, digital photogrammetry is becoming an important

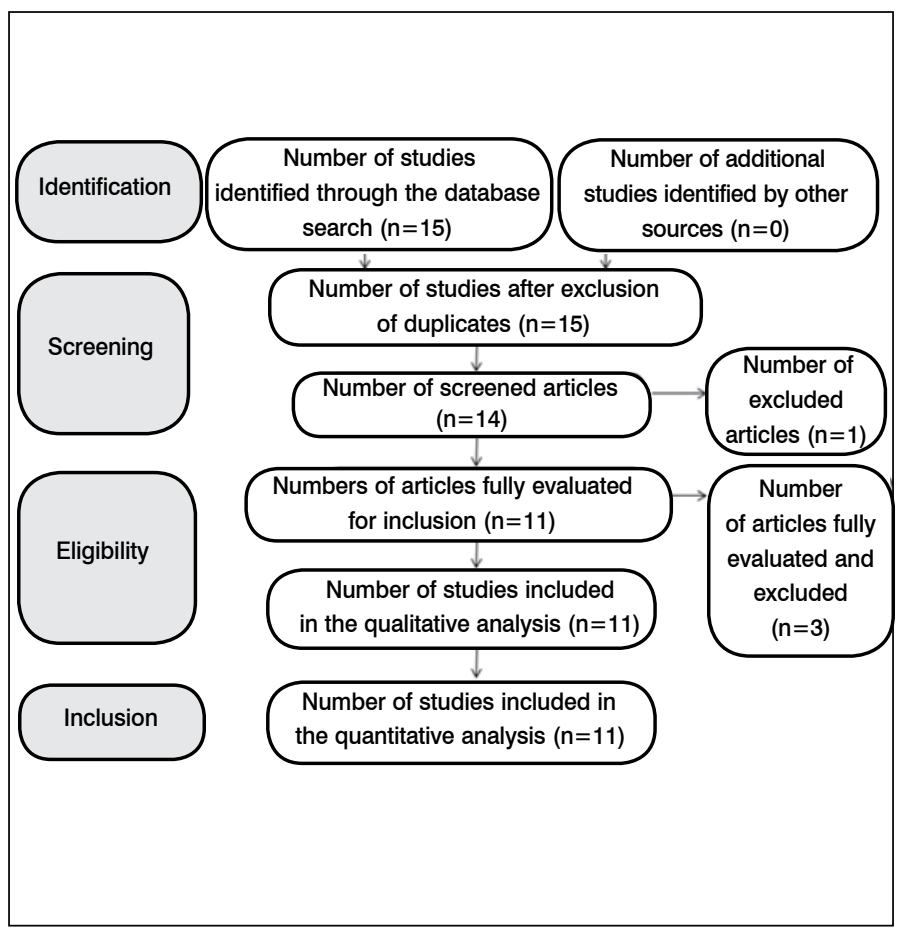

Figure 1. Flowchart of the systemic review. 
Table 1. Presentation of articles according to the year, title, authors, database of location and type of study.

\begin{tabular}{|c|c|c|c|c|}
\hline Year & Title & Authors & $\begin{array}{c}\text { Database of } \\
\text { location }\end{array}$ & Type of study \\
\hline 2002 & $\begin{array}{l}\text { Reliability and measurement } \\
\text { error of the BioTonix video } \\
\text { posture evaluation system - } \\
\text { Part I: Inanimate Objects. }\end{array}$ & $\begin{array}{l}\text { Normand } \\
\text { et al. } .^{13}\end{array}$ & $\begin{array}{l}\text { Science } \\
\text { Direct }\end{array}$ & Interventional \\
\hline 2007 & $\begin{array}{c}\text { Posture assessment of workers } \\
\text { from the railroad car repair } \\
\text { workshop of regional unit II, of } \\
\text { Companhia Vale do Rio Doce, } \\
\text { through computerized } \\
\text { biophotogrammetry. }\end{array}$ & Ramos $^{14}$ & $\begin{array}{l}\text { Google } \\
\text { Scholar }\end{array}$ & Interventional \\
\hline 2008 & $\begin{array}{l}\text { Reliability and validity of angle } \\
\text { measurements using posture } \\
\text { assessment software. }\end{array}$ & Braz et al. ${ }^{15}$ & LILACS & Interventional \\
\hline 2008 & $\begin{array}{c}\text { Assessment of static posture in } \\
\text { the frontal plane based } \\
\text { on digital imaging. }\end{array}$ & Cormelato $^{16}$ & SciELO & Interventional \\
\hline 2010 & $\begin{array}{c}\text { Assessment of postural } \\
\text { deviations in children between } \\
11 \text { and } 15 \text { years of } \\
\text { age from Porto. }\end{array}$ & Schiaffino $0^{17}$ & & Interventional \\
\hline 2011 & $\begin{array}{c}\text { Biophotogrammetry reliability of } \\
\text { measurements of the posture } \\
\text { assessment software (SAPO) } \\
\text { protocol. }\end{array}$ & Souza et al. ${ }^{6}$ & SciELO & Interventional \\
\hline 2011 & $\begin{array}{c}\text { Influence of the Camera Reso- } \\
\text { lution and Distance in Measure- } \\
\text { ments Taken by Posture Assess- } \\
\text { ment Software (SAPO). }\end{array}$ & Mota et al. ${ }^{18}$ & SciELO & Interventional \\
\hline 2011 & $\begin{array}{l}\text { Physiotherapy intervention in } \\
\text { children with brachial } \\
\text { plexus injury. }\end{array}$ & Bumba $^{19}$ & $\begin{array}{l}\text { Google } \\
\text { Scholar }\end{array}$ & Interventional \\
\hline 2011 & $\begin{array}{c}\text { The effects of water Pilates on } \\
\text { postural alteration - } \\
\text { a case study. }\end{array}$ & Sousa ${ }^{20}$ & $\begin{array}{l}\text { Google } \\
\text { Scholar }\end{array}$ & Case study \\
\hline 2012 & \begin{tabular}{|c|} 
Development of a computer \\
program for open code and \\
gratuitous posture assessment.
\end{tabular} & Noriega ${ }^{21}$ & $\begin{array}{l}\text { Google } \\
\text { Scholar }\end{array}$ & Comparative \\
\hline 2012 & $\begin{array}{c}\text { Effectiveness of Pilates method } \\
\text { for the posture and flexibility of } \\
\text { women with hyperkyphosis. }\end{array}$ & $\begin{array}{l}\text { Junges } \\
\text { et al. }{ }^{22}\end{array}$ & $\begin{array}{l}\text { Google } \\
\text { Scholar }\end{array}$ & Interventional \\
\hline
\end{tabular}

method of analysis for posture assessment, providing more reliable and objective data as it allows processes, such as: recordings, measurements and interpretations of photographic images. ${ }^{5}$ Digital photogrammetry is considered a low-cost, objective and simple technique with high precision, easy reproducibility of results and the possibility of filing records. Thus it is a precious technical element for recording postural transformations temporally, as it allows users to capture subtle transformations and to interrelate different parts of the body. ${ }^{6}$

\section{Alcimage}

A tool created by physiotherapist Mário Antônio Baraúna in partnership with professor Alcimar Soares, from the Electrical Engineering area of the Universidade Federal de Uberlândia (state of Minas Gerais), in $1999^{14}$

Alcimage is for the exclusive use of physiotherapists and is designed to quantify posture accurately based on a captured image, and to demonstrate dysfunctions through angle calculations through standardized protocols. The program is a mathematical algorithm, which transforms dots of images into Cartesian coordinate axes and quantifies them. ${ }^{14}$
Table 2. Presentation of software according to the year, creator, availability, programming language and use.

\begin{tabular}{|c|c|c|c|c|c|}
\hline Software & Year & Creator & Availability & $\begin{array}{c}\text { Programming } \\
\text { Language }\end{array}$ & Use \\
\hline Alcimage & 1999 & $\begin{array}{c}\text { Physiotherapist } \\
\text { and Electrical } \\
\text { Engineer }\end{array}$ & $\begin{array}{l}\text { Free of } \\
\text { Charge }\end{array}$ & $\begin{array}{l}\text { Information } \\
\text { nonexistent }\end{array}$ & $\begin{array}{c}\text { Physiothe- } \\
\text { rapy }\end{array}$ \\
\hline $\begin{array}{c}\text { Allbodys- } \\
\text { can 3d }\end{array}$ & $\begin{array}{c}\text { Infor- } \\
\text { mation } \\
\text { nonexis- } \\
\text { tent }\end{array}$ & \begin{tabular}{|} 
Investigators from \\
the Instituto de \\
Ciências Matemá- \\
ticas e de Com- \\
putação (ICMC) of \\
Universidade de \\
São Paulo (USP) \\
\end{tabular} & 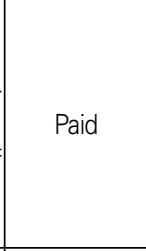 & Java & $\begin{array}{c}\text { Multi- } \\
\text { professional }\end{array}$ \\
\hline Aplob & 2012 & Engineer & $\begin{array}{l}\text { Free of } \\
\text { Charge } \\
\end{array}$ & Python & $\begin{array}{c}\text { Multi- } \\
\text { professional }\end{array}$ \\
\hline Appid & \begin{tabular}{|c} 
Infor- \\
mation \\
nonexis- \\
tent \\
\end{tabular} & $\begin{array}{l}\text { Information } \\
\text { nonexistent }\end{array}$ & $\begin{array}{l}\text { Information } \\
\text { nonexistent }\end{array}$ & MATLAB & $\begin{array}{l}\text { Information } \\
\text { nonexistent }\end{array}$ \\
\hline Biotonix & 2000 & $\begin{array}{l}\text { Information } \\
\text { nonexistent }\end{array}$ & Paid & $\begin{array}{l}\text { Information } \\
\text { nonexistent }\end{array}$ & $\begin{array}{c}\text { Multi- } \\
\text { professional }\end{array}$ \\
\hline $\begin{array}{c}\text { Corporis } \\
\text { Pro } \\
\end{array}$ & 2010 & $\begin{array}{c}\text { Data Hominis } \\
\text { Tecnologia }\end{array}$ & $\begin{array}{l}\text { Free of } \\
\text { Charge }\end{array}$ & $\begin{array}{l}\text { Information } \\
\text { nonexistent }\end{array}$ & $\begin{array}{c}\text { Multi- } \\
\text { professional }\end{array}$ \\
\hline Fisimetrix & \begin{tabular}{|c} 
Infor- \\
mation \\
nonexis- \\
tent \\
\end{tabular} & $\begin{array}{l}\text { Information } \\
\text { nonexistent }\end{array}$ & Paid & $\begin{array}{l}\text { Information } \\
\text { nonexistent }\end{array}$ & $\begin{array}{l}\text { Physiothe- } \\
\text { rapy }\end{array}$ \\
\hline $\begin{array}{c}\text { Fisiometer } \\
\text { Posturo- } \\
\text { gram }\end{array}$ & \begin{tabular}{|c|} 
Infor- \\
mation \\
nonexis- \\
tent \\
\end{tabular} & $\begin{array}{c}\text { Physiotherapist } \\
\text { and computer } \\
\text { engineer }\end{array}$ & Paid & Java & $\begin{array}{l}\text { Physiothe- } \\
\text { rapy }\end{array}$ \\
\hline $\begin{array}{c}\text { Physical } \\
\text { Fisio }\end{array}$ & $\begin{array}{c}\text { Infor- } \\
\text { mation } \\
\text { nonexis- } \\
\text { tent } \\
\end{array}$ & $\begin{array}{l}\text { Terra azul } \\
\text { tecnologia }\end{array}$ & Paid & $\begin{array}{l}\text { Information } \\
\text { nonexistent }\end{array}$ & $\begin{array}{c}\text { Physiothe- } \\
\text { rapy }\end{array}$ \\
\hline $\begin{array}{c}\text { Physio } \\
\text { Easy }\end{array}$ & 2012 & $\begin{array}{c}\text { Computer } \\
\text { engineer and } \\
\text { Physiotherapist }\end{array}$ & $\begin{array}{l}\text { Use partially } \\
\text { free of } \\
\text { charge, with } \\
\text { a fee only for } \\
\text { the use of } \\
\text { the Specia- } \\
\text { list System } \\
\text { modules }\end{array}$ & $\begin{array}{l}\text { Information } \\
\text { nonexistent }\end{array}$ & $\begin{array}{c}\text { Physiothe- } \\
\text { rapy }\end{array}$ \\
\hline $\begin{array}{l}\text { Posture } \\
\text { Print }\end{array}$ & \begin{tabular}{|c} 
Infor- \\
mation \\
nonexis- \\
tent \\
\end{tabular} & $\begin{array}{l}\text { Information } \\
\text { nonexistent }\end{array}$ & Paid & $\begin{array}{l}\text { Information } \\
\text { nonexistent }\end{array}$ & $\begin{array}{c}\text { Multi- } \\
\text { professional }\end{array}$ \\
\hline SAPO & 2005 & Physicist & $\begin{array}{l}\text { Free of } \\
\text { Charge }\end{array}$ & Java & $\begin{array}{c}\text { Multi- } \\
\text { professional }\end{array}$ \\
\hline
\end{tabular}

Six articles were found in the literature that mention this software in the methodology for such an objective. ${ }^{23-28}$ These articles emphasized that this software is safe to use and has a trustworthy performance, and is therefore reliable.

\section{All Body Scan 3D}

This software was created by investigators from the Instituto de Ciências Matemáticas e de Computação (ICMC) of Universidade de São Paulo (USP), in São Carlos. Its objective is to conduct standardized assessments of complete body composition and also of posture analysis, with use not limited exclusively to physiotherapists. ${ }^{29}$

The All Body Scan 3D scans the whole body in 30 seconds, and generates a three-dimensional model of the patient. The full body scan is performed through Kinect technology, a sensor present in 
videogames, which by means of a circular rail makes a $270^{\circ}$ turn around the patient, molding the body in 3D and transferring the volumetric data to the software in the computer, but does not scan the body over $360^{\circ} .29$

The fact that the generation of 3D models of the human body is just beginning to be explored produces weak points. Moreover, no study addressing this software has been found.

\section{Aplob}

A free-of-charge posture assessment instrument created by engineer Carlos López Noriega, ${ }^{21}$ in 2012.

Aplob requires the programming language called Python, which is commonly used in the academic community, unlike other software. ${ }^{21}$

To use Aplob you will need a camera; Styrofoam beads and a computer. ${ }^{21}$

Aplob shows potential in the following areas: accuracy proven through comparative tests with SAPO; use of the computer program (Python) which is easy to understand and under constant development, and consumption of few hardware resources. Although this software is not able to handle all the functionalities of SAPO, it has more functionalities than most posture assessment software available and enables continuous improvement of posture. ${ }^{21}$

\section{APPID}

There is no corresponding information available in the literature relating to the creator and year. This software provides qualitative and quantitative information about the posture of individuals. ${ }^{16}$

It is based on bone identification by palpation, on the use of surface markers and on the acquisition of digital images. It has two assessment stages: Assessment of posture on the sagittal plane; Assessment of posture on the frontal plane. ${ }^{16}$

Such a system requires the installation of MATLAB as a programmable mathematical tool. ${ }^{16}$

Only two studies using this tool were found. ${ }^{16,30}$ One study reports that the use of this software associated with the technique of palpation and marking of the spinous processes is a valid alternative for assessment of static posture on the frontal plane. ${ }^{16}$ The other study demonstrates that all the components of the posture assessment protocol are trustworthy, as a degree of reliability above $75 \%$ was found for all the variables, both nominal and numerical. ${ }^{30}$

\section{Biotonix}

This software was created in 2000 , entails a fee for use and is not designed exclusively for physiotherapy.

The objective of Biotonix corresponds to static posture assessment and balance. The material required for use consists of: video camera, positioning platform, personal computer and computer program. ${ }^{13}$

However, its weak point is the high resolution camera precision. The video system for posture analysis exhibits mean errors of 1.5 and $3.3 \mathrm{~mm}$, for angle and distance, respectively. This tool is also considered valid, and is recommended for posture analysis. ${ }^{13}$

Two articles were found in the current literature correlating such a tool. ${ }^{18,31}$ The first merely mentioned it while the second used it as a tool for posture assessment, which indicated that the video system of Biotonix had a high degree of reliability and validity, and that this system is thus suitable for clinical use in posture analysis.

\section{Corporis pro}

This tool was created in 2010 and can be downloaded for free although there is a paid license.

Its objective is the performance of posture assessment of patients, kinesiology studies and motion analysis, and it makes it possible to manage users, patients or research subjects, to capture images from different sources and to process them by means of a large set of tools. ${ }^{32}$

It requires the Microsoft SQL (database management system) platform to function. ${ }^{32}$ We found one study using this tool, ${ }^{33}$ relating temporomandibular dysfunction with posture.

\section{Fisimetrix}

The creator and year are not known, and its system entails a fee. Its objective is the performance of orthopedic postural assessment as well as the preparation of reports on postural abnormalities. ${ }^{19}$

The patient is assessed through photogrammetric images in the anterior, posterior, left and right lateral views. ${ }^{19}$

Its weak point is that it has no reference values. ${ }^{17,19}$

We found three studies using this posture assessment software, ${ }^{17,20,22}$ which emphasized that there are no known pathology indicator reference values for measurements taken from this application.

\section{Fisiometer posturogram}

This software was developed by Francinett Dias (physiotherapist) and Hémerson Antônio da Silva (computer engineer). However, we did not find any information in literature about year or place of creation. The software consists of a tool for joint, muscle complex and nerve assessment. ${ }^{34}$

Its objective is to provide computerized support to physiotherapists and professionals from similar areas.

The functional evaluation is standardized and performed in six photos in the upright position. This software does not have a source of reference on assessment and available treatment. To record the images in the assessments it is recommended to use a digital camera with one mega pixel or above. ${ }^{34}$

We found two articles using this tool in the literature. ${ }^{35,36}$ These articles emphasized that the use of this software is reproducible, and that it can be used as a posture assessment instrument in qualitative and quantitative methodologies.

\section{Physical Fisio}

This is a system produced by Terra Azul Tecnologia more than 20 years ago that costs between 300 and 400 US dollars. It consists of posture evaluation software with the following phases: Anamnesis; Measurement of perimeters; Body composition analysis; Evaluation of flexibility and posture. ${ }^{37}$

This tool has inclusion of photos, videos and incident sheets. However, it does not encourage the therapist to follow their own protocol, as there are several built into its system, besides having few tests for each assessment. This software is designed for use exclusively in physiotherapy. ${ }^{37}$ We did not find any article about this software.

\section{Physio Easy}

This tool was created by computer engineer Glauco Cardozo in partnership with physiotherapist Maíra Junkes. ${ }^{38}$ It is a posture assessment system not intended specifically for physiotherapy, composed of computerized biophotogrammetry tools and a specialized system, capable of assisting in clinical decision making. ${ }^{38}$

This assessment instrument is composed of tools for linear and angular measurement, besides many other auxiliary tools. Each object measured in the images can be easily moved or edited, enhancing the versatility of measurements. Users require the Software Shell Intellec System. ${ }^{38}$

Only one study was found using the corresponding software. ${ }^{39}$ This study emphasized that the use of this software can help any healthcare professional to make clinical decisions, particularly because of its easy use.

\section{Posture Print}

The year and place of creation and the creator of this software were not found. Posture Print is a tool with a posture assessment system that detects postural deviations and automatically identifies and prescribes the correct posture for a particular individual. ${ }^{40}$

To execute its function, the system generates a report with images of the patient's posture and center of gravity displacement data together with the prescription of correct exercise and a logbook, with a standardized assessment. However, it may undergo changes depending on how the professional wishes to use it. This software is not specifically intended for physiotherapists. ${ }^{40}$ 
The weak point of this program is the lack of therapist assessment incentive, besides the fact that it costs between 400 and 500 dollars to obtain the license. ${ }^{40}$ We did not find any articles about this software.

\section{SAPO}

This tool was created by professor Marcos Duarte in 2003 at the Universidade de São Paulo. Access is free of charge and the software was not designed exclusively for physiotherapy. ${ }^{41}$

The tool has the following objectives: Posture analysis; To generate a database on posture with information from various research sites and to provide information about postural control. It is based on scanning and enables sundry functions, such as: image calibration, use of zoom, free marking of points, measurement of distances and of body angles, with assessment either standardized or specifically directed by the professional. ${ }^{30}$

Its weak points are the non-standardization of anatomical references and the absence of the meaning of angle measurements used in the studies with photogrammetry. These factors hinder a comparison between studies and the actual validation of the results found. ${ }^{6}$

It needs JAVA programming language whose installation is required for the functioning of the software, besides a camera, Styrofoam beads, and a computer. ${ }^{15}$

Various articles related to SAPO can be found in the literature, $6,15,41-48$ hence it is the software with the largest number of publications at present. These articles emphasize that the use of this software is reliable and valid for measuring angle values in body segments.
In view of the above, note that there is a significant range of software to assist in posture assessment, yet only one tool has a larger amount of information and related studies: SAPO. A study reports that this software is a reliable and valid alternative for taking angle measurements in the body segments, when compared to goniometry, provided that its technical requirements are fulfilled, ${ }^{15}$ and that the angles proposed by the SAPO protocol have shown themselves to be reliable after inter-examiner evaluation for measuring body segments. ${ }^{6}$

This study can be used as a starting point for further surveys with the intention of addressing and comparing the other types of software, knowledge of healthcare professionals and patients of the usefulness of posture assessment software, and others, with the confirmation and improvement of their use as an assumption.

\section{FINAL CONSIDERATIONS}

There is plenty of posture analysis software available on the Internet nowadays. However, although the software has similar applicability, functioning methodology and objectives, these are considerably disparate in terms of the possibilities of response, and the software has not yet been well publicized as a research tool.

All authors declare no potential conflict of interest concerning this article.

\section{REFERENCES}

1. Contri DE, Petrucelli A, Perea DCBNM. Incidência de desvios posturais em escolares do $2^{\circ}$ ao $8^{\circ}$ ano do ensino fundamental. Conscientiae Saúde. 2009; 8(2):219-24.

2. Oshiro VA, Ferreira PG, Costa RF. Alterações posturais em escolares: uma revisão da literatura. RBCS. 2007;3(13):15-22

3. Nicolino ACBS. Fisioterapia preventiva através de orientação postural para crianças em idade escolar [monografia]. Lins: Centro Universitário Católico Salesiano Auxilium (UNISALESIANO); 2007.

4. Braccialli LMP, Vilarta R. Aspectos a serem considerados na elaboração de programas de prevenção e orientação de problemas posturais. Rev Paul Educ Fís. 2000:14(2):159-71.

5. Sacco ICN, Alibert S, Queiroz BWC, Pripas D, Kieling I, Kimura AA, et al. Confiabilidade da fotogrametria em relação a goniometria pra avaliação postural de membros inferiores. Rev Bras Fisioter. 2007;11(5):411-17.

6. Souza JÁ, Pasinato F, Basso D, Castilhos E, Correa R, Silva AMT. Biofotogrametria confiabilidade das medidas do protocolo do software para avaliação postural (SAPO). Rev Bras Cineantropom Desempenho Hum. 201;13(4):299-305.

7. Watson AW, Mac Donncha C. A reliable technique for the assessment of posture: assessment criteria for aspects of posture. J Sports Med Phys Fitness. 2000:40(3):260-70.

8. Mansoldo AC, Nobre DPA. Avaliação postural em nadadores federados praticantes do nado borboleta nas provas de 100 e 200 metros. Mundo da Saúde 2007;31(4):511-20.

9. Jeferry M. Using digital image processing for the assessment of postural changes and movement patterns in bodywork clients. J Bodyw Mov Ther. 2001;5(1):11-20.

10. SatoTO, Viera ER, Gil-Coury HJC. Análise de confiabilidade de técnicas fotométricas para medir a flexão anterior do tronco. Rev Bras Fisioter. 2003:7(1):53-99.

11. Santos $\mathrm{Cmc}$, Pimenta Camp, Nobre Mrc. A estratégia Pico para a construção da pergunta de pesquisa e busca de evidências. Rev Latinoam. Enfermagem. 2007;15(3):508-51.

12. Mendes KDS, Silveira RCCP, Galvão CM. Revisão Integrativa: Método de pesquisa para a incorporação de evidências na saúde e na enfermagem. Texto Contexto Enferm. 2008;17(4):758-64

13. Normand MC, Harrison DE, Cailliet R, Black P, Harrison DD, Holland B. Reliability and measurement error of the BioTonix video posture evaluation system-Part I: Inanimate objects. J Manipulative Physiol Ther. 2002;25(4):246-50.

14. Ramos, D. Avaliação da postura corporal dos trabalhadores da oficina de reparo de vagões da regional II, da companhia Vale do Rio Doce, através da biofotogrametria computadorizada [dissertação]. Minas Gerais: Centro Universitário de Caratinga; 2007.

15. Braz RG, Goes FPDC, Carvalho GA. Confiabilidade e validade de medidas angulares por meio do software para avaliação postural. Fisioter. Mov. 2008;21(3):117-26.
16. Cormelato T. Avaliação da postura corporal estática no plano frontal a partir de imagem digital [dissertação]. Porto Alegre: Universidade Federal do Rio Grande do Sul; 2008.

17. Schiaffino AN. Avaliação de desvios posturais em crianças entre 11 e 15 anos do Porto [dissertação]. Porto: Universidade do Porto; 2010.

18. Mota YL, Mochizuki L, Carvalho GA. Influência da resolução e da distância da câmera nas medidas feitas pelo software de avaliação postural (sapo). Rev Bras Med Esporte 2011:17(5):334-38

19. Bumba ZCA. Intervenção fisioterapêutica em crianças com lesão do plexo braquial [monografia]. Criciúma: Universidade do Extremo Sul Catarinense (UNESC); 2011.

20. Sousa EIP. Os efeitos de Water Pilates sobre a alteração postural - um estudo de caso. [monografia]. Criciúma: Universidade do Extremo Sul Catarinense (UNESC); 2011.

21. Noriega CP. Desenvolvimento de um programa computacional para avaliação postural de código aberto e gratuito [dissertação]. São Paulo: Instituto de Psicologia da Universidade de São Paulo; 2012.

22. Junges S, Gottlieb MG, Baptista RR, Quadros CB, Resende TL, Gomes I. Eficácia do método pilates para a postura e flexibilidade em mulheres com hipercifose. Rev Bras Cienc Mov. 2012:20(1):21-33.

23. lunes DH, Castro FA, Salgado HS, Moura IC, Oliveira AS, Bevilaqua-Grossi D. Confiabilidade intra e interexaminadores e repetibilidade da avaliação postural pela fotogrametria. Rev Bras Fisioter. 2005:9(3):327-34.

24. Baraúna MA, Morais EG, Oliveira ATM, Domingos LG, Sanchez HM, Silva RAV, et al. Estudo correlacional e comparativo entre ângulo axilar e assimetria de ombro através de um protocolo biofotogramétrico. Rev Bras Fisioter Mov. 2006:19(1):17-24.

25. Motta LJ, Martins MD, Fernandes KPS, Mesquita-Ferrari RA, Biasotto-Gonzalez DA, Bussadori SK. Relação da postura cervical e oclusão dentária em crianças respiradoras orais. Rev. CEFAC 2009;11(Supl 3):298-304

26. Lacerda FMC, Santiago HVP, Chiapeta A. Análise comparativa da postura dos acadêmicos dos cursos de Direito,Ciências contábeis, Fisioterapia e Educação Física das Faculdades Sudamérica de Cataguases, MG. EFDeportes. 2011;16(156).

27. Carvalho RMF, Mazzer N, Barbieri $\mathrm{CH}$. Análise da confiabilidade e reprodutibilidade da goniometria em relação à fotogrametria na mão. Acta Ortop Bras. 2012;20(3):139-49.

28. Santos ACA, Capeleti LA, Fantinati, AMM, Guimarães AAP, Di Naccio BL. Análise do software alcimage utilizado na avaliação postural. Movimenta 2013:6(2):450-5.

29. All Body Scan 3D Avaliação postural [Internet]. [acesso em 2014 ago 10]. Disponível em: www.allbodyscan3d.com.br

30. Furlanetto TS, Chaise FO, Candotti CT, Loss JF. Fidedignidade de um protocolo de avalia- 
ção postural. Rev Ed Fís/UEM. 2011;22(3):411-9.

31. Guimond S, Massrieh W. Intricate correlation between body posture, personality trait and incidence of body pain: a cross-referential study report PLoS One 2012:7(5):e37450.

32. DataHominis Tecnologia. Corporis Pro [Internet]. [acesso em 2014 ago 10]. Disponível em: www.datahominis.com.br/corporispro/corporispro/caracteristicas.html.

33. Aoyama AY, Pavia A, Pachioni CAS, Faria CRS, Ferreira DMA. Disfunção temporomandibular e sua relação com a postura. Colloquium Vitae 2011;3(Especiall):270-6.

34. Fisiometer Posturograma [Internet]. lacesso em 2014 jun 28]. Disponivel em: www. fisiometer.com.br

35. Venturelli WS. Correlação das alterações posturais e da espirometria de crianças respiradoras bucais [dissertação]. Rio de Janeiro: Faculdade de Medicida Universidade Federal do Rio de Janeiro; 2006.

36. Mansoldo AC, Nobre Dpa. Postural evaluation in practicing federate butterfly swimmers in the tests for 100 and 200 meters. Mundo da Saúde. 2007:31(4):511-520.

37. Terrazul Tecnologia. Software Physical Fisio [Internet]. lacesso em 2014 jun 28]. Disponível em: www.terrazul.com.br/site/produtos/19/Software-de-Fisioterapia/Physical-Fisio

38. Physio Easy. Avaliação postural [Internet]. [acesso 2014 jun 27]. Disponível em: www. physioeasy.com.br/pages/home.php.

39. Cardozo G. Sistema de avaliação postural para suporte no processo de decisão clínica. [dissertaçăol. Florianóplois: Universidade Federal de Santa Catarina; 2012.

40. postureprint. The Ultimate in Precision Postural Evaluation [Internet]. [acesso em 2014 jun 28].
Disponivel em: www.postureprint.org.

41. Ferreira EAG. Postura e controle postural: desenvolvimento e aplicação de método quantitativo de avaliação postural. [tese]. São Paulo: Faculdade de Medicina da Universidade de São Paulo; 2005

42. Galera SRGP. Estudo comparativo da postura de indivíduos com e sem dor na coluna vertebral [monografial. Guaratinguetá: Universidade Estadual Paulista (UNESP): 2007.

43. Peres S, Simão R, Lima C, Souza, lamut ME, Estrazulas J, et al. Avaliação bidimensional da postura de atletas de alto rendimento. Fit Perf J. 2007;6(4):247-50.

44. Barreto CG, Morais JC, Morandi MRB, Lsensee RM, Lopes RB. Correlação da abdução escapular com a função pulmonar e pressões respiratórias máximas em portadores de DPOC. Rev Bras Fisioter. 2008;12(Suppl.):104.

45. Pasinato F, Corrêa EC, Souza JA. Avaliação fotogramétrica da postura da cabeça e coluna cervical de indivíduos com disfunção temporomandibular. Ter Man. 2009;7(29):47-53.

46. Gomes J, Palma M, Sampaio O, Vasconcelos N, Barbosa TM. Análise comparativa da postura ortostática entre mulheres fisicamente activas e sedentárias [Anais]. In: $4^{\circ} \mathrm{Con}-$ gresso Nacional de Biomecânica, Coimbra, Portugal; 2011. p. 717-9.

47. Gimenes RO, Tacani PM, Garbellotti-Junior SA, Campos CM, Batista PAN. Fisioterapia aquática e de solo em grupo na postura de mulheres mastectomizadas. J. Health Sci. Inst. 2013;31(1):79-83.

48. Ferreira EAG, Duarte M, Maldonado EP, Burke TN, Marques AP. Postural assessment software (PAS/SAPO): validation and reliabiliy. Clinics. 2010;65(7):675-81. 